\title{
A Comparative Study of QWL among University Teachers
}

\author{
Kawaljit Kaur ${ }^{1}$, Dhiraj Sharma ${ }^{2}$ \\ ${ }^{1}$ (Assistant Professor, P.G. Department of Commerce and Management, Khalsa College, Amritsar) \\ 2 (Assistant Professor, School of Management Studies, Punjabi University, Patiala) \\ ( ${ }^{1}$ bhatiaasr@gmail.com, ${ }^{2}$ dhiraj.pbiuniv@gmail.com)
}

\begin{abstract}
Purpose -It is utmost important to retain competent employees for the success of every organization. Mere use of money, technology and infrastructure could not bring success to an organization unless and until its employees are satisfied. For employee satisfaction, employees must be self motivated. Thus objective of this study is to analyze what factors affect quality of work life of faculty members working in public and private sector universities in Punjab. Design/ Methodology - Data were collected from total six universities of Punjab state of India (Three Government and Three Private Universities). Faculty members teaching in different universities were the sampling unit for present study. Faculty members were asked to fill questionnaire. Findings - As far as comparative study is concerned; factors which motivates to both sector's employees to work efficiently are salary \& rewards, better leave plans, reasonable working hours and opportunities for promotion. There are few factors, which create aversion among employees both sectors are; too much workload, conduct of top management, long travelling hours and internal politics. Originality- Although vast literature exists about quality of work life in different sectors but, yet, hardly very few studies have been conducted in India to investigate $Q W L$ in higher education sector particularly in Punjab. Present study adds to the literature by scour into this aspect in Indian higher education sector.
\end{abstract}

Keywords: Compensation, Job Satisfaction, Motivation, Quality of work life, University, Work load.

\section{INTRODUCTION}

Quality of work life refers to the level of pleasure or displeasure with one's own career. The employees who enjoy their career are said to have a high quality of work life, while who are not satisfied with their job have a low quality of work life. Various variables are taken which affect quality of work life of both Government and Private University Teachers. For the success of every organization it is utmost important to retain competent employees. Mere use of money, technology and infrastructure could not bring success to an organization unless and until its employees are satisfied. For employee satisfaction; employees must be self motivated. As mentioned in hygiene two factor theory, the presence of hygiene factors do not create satisfaction but absence of these definitely create dissatisfaction (Herzberg 1923). Due to changes in work environment i.e. technological, high competition, rise of employee unions etc.; employers are not only offering pay as compensation, but are considering other benefits both intrinsic \& extrinsic to create a quality working environment that will attract and retain the best brains in the industry. The quality of work life can be explained as the quality of association among the employees and the work surroundings such that the employees have an important pressure in structuring the organizational surroundings in techniques utilized to rise not only their personal inspiration and job satisfaction but also the profits and productivity of the organization. The quality of work life covers numerous areas like getting rid of the health hazards for the employees, sufficient fair compensations, security of job, benefits for employees, profit sharing, work schedules and the work place contribution. As far as comparative study is concerned; factors which motivates both sector's employees to work efficiently are salary \& rewards, better leave plans, reasonable working hours and opportunities for promotion. Employees often experts various quality requirement from work place, these can be classified into personal anticipatory, motivational insights, job freedom and working conditions. A worker must have an optimistic awareness of QWL in the organization. She / he should possibly struggle to further develop the working conditions, raise the quality and production of products (Runcie, 1980). The knowledge of a fair number of firms shows that a number of particular structures, roles and the systems of support must be in position and 
functioning efficiently in order that the programs of quality of work life stay feasible grow, engage, infuse the culture of the organization and create long term benefits and success. The experiences cross nation sufficiently reveal that development in quality of work life has exact scope and potential in civilizing the productivity (Ledford and Lawler, 1982) and the whole effectiveness of the organization (Buchanan and Boddy, 1982) as also decreasing the turnover, absenteeism, grievances (Goodman, 1980) and accidents in the industry (Havolovic, 1991).

\section{PREVIOUS RESEARCH}

The most contented teachers are the ones who feel their jobs are secure and they are treated as experts by the community. This is one of the key factors as this ensures that they are capable of delivering the student requirement and they are capable of utilizing their overall skills (Walton et al., 2003). Teachers whose jobs are secure are more likely to have prospects for professional development, interact cohesively with peers and greater parental involvement in their schools and to their students (Gupta \& Sharma, 2011). Rewards and Benefits serves as a motivating factor for teachers to perform well in the colleges. This also creates a healthy competition between teachers in using their overall skills in their performance and strives to increase the overall standard of the college (Kaur, 2012). Compensation plays a pivotal role in effectiveness of the university. Lesser compensation would not attract skilled and experienced people with great performance and would not help in achieving the quality in imparting education, while higher compensation might be an overhead with costs running more than the desired (Malarvizhi, 2012; Islam, 2012). University should strive to provide opportunity for every team member to showcase their talent, proficiency, skills, capacity and abilities (Zakari, Khamis \& Hamadi, 2010). Utilizing teacher's capacities in areas other than their present position will help them to understand that management appreciates and identifies that what the staff could provide to the university. This can also provide work variety and helps to break up the everyday grind of work and also helps to get free from the stress of the routine work (Gupta \& Sharma, 2011). Teachers will be dissatisfied if rational climate doesn't exist for them to differentiate work from family (Carr et al. 2003). The universities demand shouldn't be interfering with teacher's family responsibilities and personal duties apart from their carrier (Aziz et al., 2010; Al-Enezi et al. eds., 2009). Teachers experience poor mental health and lower job satisfaction as compared to other groups (Miller and Travers 2005). There is an association between the quality of work life with the commitment to university among some 205 students who possess the student job and it is found that there is a considerable association among the willingness to work and the commitment to university (Turner 2005) whereas there is a significant and positive association between the organizational commitment and the quality of work life (Ashoob 2006). Disappointment with quality of work life may affect faculties irrespective of their positions. When the universities starts to identify that the faculties have their lives apart from work, trust and loyalty among faculties is created (Saraji and Dargahi, 2006). Workload pressure, role ambiguity and performance pressure were the predictors of job stress. But managerial role and relationship with others had no significant direct effect on job stress (Alam 2009). As far as association in the perception of employees towards quality of work life and job satisfaction across the gender and nature of job is concerned there is difference in the perception of males and females with regard to different dimensions like working conditions, work life balance, opportunities of growth and social relevance of job (Shalla et al.2014).

\section{RESEARCH GAP}

The review of the existing literature reveals that a numbers of studies have been carried out on various aspects of quality but a very few comprehensive studies in this area could be found which provides detailed information regarding quality of work life in universities of Punjab region. In the light of the above discussion comprehensive and detailed study regarding universities is of dire need. Since these teachers are the only scapegoat of these universities, the comparison of the quality of their work lives in universities will be an eye opener to private as well as public sector universities in Punjab in improving the work environment of these faculties. 


\section{NEED AND Aim OF STUdY}

This study aims to analyze what factors affecting quality of work life of faculty members working in public and private sector universities in Punjab. To achieve organizational goals it is necessary that its employees must be ready to work with zeal and enthusiasm. For this purpose, efficient working conditions should be provided to them. The word government and public sector university are used interchangeably in this study.

\section{METHODOLOGY}

The present study is based on primary data and secondary data. In this research, primary data is collected from faculty members of government and private universities of Punjab, with the help of questionnaire. The questionnaire is developed for the respondents and it is specifically based upon the objectives of this study. The secondary data have also been collected from journals, books and various committees such as Yash Pal Committee report 2009, CSO (2008) Statistical Abstracts of Punjab. Universities were selected on the basis of quota sampling and respondents were selected on the basis of random sampling. The survey was conducted via email and face to face interviews. The sample size is an important feature of an empirical study in which goal is to make inferences about a population from a sample. A total of 550 survey questionnaires had been sent, to which 510 questionnaires received back. Each of the responses received had been screened for errors or incomplete responses. However, responses that had more than $25 \%$ of the questions in the survey questionnaire left unanswered that had been discarded from data analysis. After the screening process carried out, only 500 (250 from each sector) responses have been considered complete and valid for data analysis. Keeping into consideration the objectives of the study, a structured questionnaire was prepared to meet the objectives. The questionnaire was framed on the basis of previous literature, discussion with experts of the related field. The suggestions of experts led to many meaningful modifications. The preliminary draft was pre tested on 50 respondents, including 25 from public sector universities and 25 from private sector universities. Questionnaires were received back with suggestions; questionnaires were revised and sent for final survey. All the questions were close ended. Factor analysis was used to analyze the data.

\section{ANALYSIS AND CONCLUSIONS}

These were in general; reflecting perception of faculty members of Public and Private Universities. The statements were short listed on the basis of review of previous studies (Walton, 1972; Gordon, 1984 and Gilgeous, 1998), discussion with experts and institutions. Faculty members were asked to express their level of agreement/ disagreement with respect to various statements based on five-point Likert scale. Factor analysis is applied to summarize the data into less and meaningful factors relevant to the sample.

\section{PERCEPTION OF GOVERnMENT UNIVERSITY TEACHERS -A FACTOR ANALYSIS APPROACH}

Data were examined for its suitability for factor analysis. Reliability is measured by using Crohnbach's Alpha. Crohnbach's Alpha ranges from 0 to 1 . The Crohnbach's Alpha of likert scaled items in the questionnaire was 0.732 which is deemed to be good. This was done by computing the correlation matrix which was depicted enough correlations to carry out factor analysis. Correlation matrix was computed which depicted that there were enough correlations to carry out factor analysis. Communality and factor loadings were high enough to prove the suitability of data as well as the Kaiser-Meyer-Oklin measure of sampling adequacy (KMO) was 0.715 which indicated that the sample was good enough for sampling. Barlett's Test of Sphericity showed statistically significant number of correlations among the variables. Hence all the above mentioned parameters revealed that data was fit for factor analysis. The Eigen values are the total variance attributed to that factor. Any factor that has an Eigen values of less than 1 does not have enough total variance explained to represent a unique factor and is therefore disregarded. The Eigen values represent the total variance explained by each factor. Out of 34 statements listed for 
assessing quality of work life after applying factor analysis total variance that 12 factors extracted together for $62.357 \%$ of total variance so it is possible to economize on the number of variables from 34 to 12 .

The $1^{\text {st }}$ factor explains the largest portion of the total variance. The $2^{\text {nd }}$ factor for the most of the residual variance, subject to being uncorrelated with the first factor. The second factor explains the second highest variance and so on. The Eigen values for the factors are in decreasing order of magnitude as we move from variable 1 to variable 12 . Factor 1 accounts for a variance 4.885 which (4.885/34) or $14.367 \%$ of the total variance. Likewise the second factor accounts for $(2.566 / 3.4)$ or $7.548 \%$ of total variance and so on. All factor loadings greater than 0.5 have been considered for factor analysis.

TABLE I. Principal Component Analysis with Varimax Rotation- Public Sector University

\begin{tabular}{|c|c|c|c|c|c|c|c|}
\hline $\begin{array}{c}\text { Factor } \\
\text { Number }\end{array}$ & $\begin{array}{c}\text { Name of } \\
\text { Dimension }\end{array}$ & Label & Statement & $\begin{array}{c}\text { Factor } \\
\text { loadings }\end{array}$ & $\begin{array}{l}\text { Eigen } \\
\text { Values }\end{array}$ & $\begin{array}{c}\% \text { of } \\
\text { Variance }\end{array}$ & $\begin{array}{c}\% \text { of } \\
\text { Cumulative } \\
\text { Variance }\end{array}$ \\
\hline 1 & $\begin{array}{c}\text { Job Satisfaction } \\
\text { and } \\
\text { Self Esteem }\end{array}$ & $\begin{array}{l}\mathrm{F}_{3} \\
\mathrm{~F}_{12} \\
\mathrm{~F}_{13} \\
\mathrm{~F}_{16}\end{array}$ & $\begin{array}{l}\text { Good Relationship } \\
\text { with co-workers } \\
\text { Faculty members } \\
\text { have friendly } \\
\text { relations with each } \\
\text { other } \\
\text { Fellow colleagues } \\
\text { are ready } \\
\text { I feel satisfied after } \\
\text { performing my work }\end{array}$ & $\begin{array}{l}0.639 \\
0.669 \\
0.708 \\
0.584\end{array}$ & 4.88 & 7.96 & 7.96 \\
\hline 2 & $\begin{array}{c}\text { Effect } \\
\text { Recognition and } \\
\text { Career } \\
\text { Progression }\end{array}$ & $\begin{array}{l}\mathrm{F}_{7} \\
\mathrm{~F}_{8} \\
\mathrm{~F}_{9} \\
\mathrm{~F}_{10} \\
\mathrm{~F}_{24}\end{array}$ & $\begin{array}{l}\text { Sufficient } \\
\text { motivational } \\
\text { strategies } \\
\text { Support from the top } \\
\text { management is } \\
\text { helpful in } \\
\text { accomplishing a } \\
\text { task } \\
\text { University } \\
\text { recognizes and } \\
\text { acknowledge my } \\
\text { work } \\
\text { Adequate } \\
\text { opportunities for } \\
\text { self improvement } \\
\text { and career } \\
\text { progression } \\
\text { All the faculty } \\
\text { member generally }\end{array}$ & $\begin{array}{l}0.577 \\
0.628 \\
0.643 \\
0.515 \\
0.695\end{array}$ & 2.56 & 7.30 & 15.27 \\
\hline
\end{tabular}




\begin{tabular}{|c|c|c|c|c|c|c|c|}
\hline $\begin{array}{c}\text { Factor } \\
\text { Number }\end{array}$ & $\begin{array}{c}\text { Name of } \\
\text { Dimension }\end{array}$ & Label & Statement & $\begin{array}{c}\text { Factor } \\
\text { loadings }\end{array}$ & $\begin{array}{l}\text { Eigen } \\
\text { Values }\end{array}$ & $\begin{array}{c}\% \text { of } \\
\text { Variance }\end{array}$ & $\begin{array}{c}\% \text { of } \\
\text { Cumulative } \\
\text { Variance }\end{array}$ \\
\hline & & & $\begin{array}{l}\text { support all the } \\
\text { members of the } \\
\text { universities }\end{array}$ & & & & \\
\hline 3 & $\begin{array}{l}\text { Employee } \\
\text { loyalty and } \\
\text { Growth }\end{array}$ & $\begin{array}{l}\mathrm{F}_{5} \\
\mathrm{~F}_{15} \\
\mathrm{~F}_{28} \\
\mathrm{~F}_{29}\end{array}$ & $\begin{array}{l}\text { Effective } \\
\text { promotional } \\
\text { opportunities in the } \\
\text { university } \\
\text { On the basis of my } \\
\text { own standards, I am } \\
\text { satisfied with } \\
\text { personal } \\
\text { development } \\
\text { Faculty members in } \\
\text { this university } \\
\text { communicate well } \\
\text { with each other } \\
\text { All the members are } \\
\text { generally committed } \\
\text { to their work }\end{array}$ & $\begin{array}{l}0.584 \\
0.510 \\
0.787 \\
0.587\end{array}$ & 1.87 & 6.03 & 21.30 \\
\hline 4 & $\begin{array}{l}\text { Quality on } \\
\text { Work Place }\end{array}$ & $\begin{array}{l}\mathrm{F}_{20} \\
\\
\\
\mathrm{~F}_{17}\end{array}$ & $\begin{array}{l}\text { I feel that my } \\
\text { university provides } \\
\text { maximum facilities } \\
\text { for doing my work } \\
\text { properly } \\
\text { I feel good about the } \\
\text { quality of work } \\
\text { performed }\end{array}$ & $\begin{array}{l}0.688 \\
0.515\end{array}$ & 1.70 & 4.92 & 26.22 \\
\hline 5 & $\begin{array}{l}\text { Conducive } \\
\text { Environment }\end{array}$ & $\begin{array}{l}\mathrm{F}_{6} \\
\mathrm{~F}_{22}\end{array}$ & $\begin{array}{l}\text { Good safety } \\
\text { measures adopted at } \\
\text { the university } \\
\text { I do not feel under } \\
\text { pressure from } \\
\text { anybody in carrying } \\
\text { out my duties }\end{array}$ & $\begin{array}{l}0.725 \\
0.579\end{array}$ & 1.52 & 4.89 & 31.12 \\
\hline 6 & $\begin{array}{l}\text { Lower Self } \\
\text { Esteem }\end{array}$ & $\begin{array}{l}\mathrm{F}_{18} \\
\mathrm{~F}_{27}\end{array}$ & $\begin{array}{l}\text { There are many } \\
\text { political problems in } \\
\text { this University } \\
\text { Most of my }\end{array}$ & $\begin{array}{l}0.816 \\
0.574\end{array}$ & 1.47 & 4.82 & 35.94 \\
\hline
\end{tabular}




\begin{tabular}{|c|c|c|c|c|c|c|c|}
\hline $\begin{array}{c}\text { Factor } \\
\text { Number }\end{array}$ & $\begin{array}{c}\text { Name of } \\
\text { Dimension }\end{array}$ & Label & Statement & $\begin{array}{l}\text { Factor } \\
\text { loadings }\end{array}$ & $\begin{array}{l}\text { Eigen } \\
\text { Values }\end{array}$ & $\begin{array}{c}\% \text { of } \\
\text { Variance }\end{array}$ & $\begin{array}{c}\% \text { of } \\
\text { Cumulative } \\
\text { Variance }\end{array}$ \\
\hline & & & $\begin{array}{l}\text { activities are routine } \\
\text { and boring }\end{array}$ & & & & \\
\hline 7 & $\begin{array}{c}\text { Employee } \\
\text { Development }\end{array}$ & $\begin{array}{l}F_{21} \\
F_{34}\end{array}$ & $\begin{array}{l}\text { I am developing } \\
\text { new skills and } \\
\text { abilities at work } \\
\text { My superior always } \\
\text { allows to attend } \\
\text { refresher courses } \\
\text { and conferences }\end{array}$ & $\begin{array}{l}0.704 \\
0.558\end{array}$ & 1.41 & 4.67 & 40.62 \\
\hline 8 & $\begin{array}{l}\text { Work load other } \\
\text { than teaching }\end{array}$ & $\begin{array}{l}\mathrm{F}_{32} \\
\mathrm{~F}_{33}\end{array}$ & $\begin{array}{l}\text { I feel too much } \\
\text { burdened for } \\
\text { research work. } \\
\text { My university } \\
\text { organizes FD for the } \\
\text { up gradation of } \\
\text { facility }\end{array}$ & $\begin{array}{l}0.582 \\
0.815\end{array}$ & 1.30 & 4.48 & 45.10 \\
\hline 9 & Rationality & $\begin{array}{l}\mathrm{F}_{11} \\
\mathrm{~F}_{25}\end{array}$ & $\begin{array}{l}\text { Favoritism does not } \\
\text { play any part in the } \\
\text { institution of work } \\
\text { Faculty members } \\
\text { are given } \\
\text { recognition for their } \\
\text { creative work }\end{array}$ & $\begin{array}{l}0.754 \\
0.511\end{array}$ & 1.18 & 4.46 & 49.57 \\
\hline 10 & $\begin{array}{c}\text { Organizational } \\
\text { satisfaction }\end{array}$ & $\begin{array}{l}\mathrm{F}_{2} \\
\mathrm{~F}_{14}\end{array}$ & $\begin{array}{l}\text { Job security exists at } \\
\text { my university. } \\
\text { I feel that my } \\
\text { superiors give } \\
\text { reasonable attention } \\
\text { to my suggestions as } \\
\text { regards method of } \\
\text { work }\end{array}$ & $\begin{array}{l}0.741 \\
0.566\end{array}$ & 1.15 & 4.30 & 53.88 \\
\hline 11 & $\begin{array}{c}\text { Organizational } \\
\text { communication } \\
\text { and economic } \\
\text { benefit }\end{array}$ & $\begin{array}{l}\mathrm{F}_{1} \\
\\
\mathrm{~F}_{23}\end{array}$ & $\begin{array}{l}\text { There is a } \\
\text { reasonable } \\
\text { periodical increase } \\
\text { in salary } \\
\text { There is an active } \\
\text { low of ideas }\end{array}$ & 0.501 & 1.08 & 4.26 & 58.15 \\
\hline
\end{tabular}




\begin{tabular}{|l|c|l|l|c|c|c|c|}
\hline $\begin{array}{c}\text { Factor } \\
\text { Number }\end{array}$ & $\begin{array}{c}\text { Name of } \\
\text { Dimension }\end{array}$ & Label & Statement & $\begin{array}{c}\text { Factor } \\
\text { loadings }\end{array}$ & $\begin{array}{l}\text { Eigen } \\
\text { Values }\end{array}$ & $\begin{array}{c}\text { \% of } \\
\text { Variance }\end{array}$ & $\begin{array}{c}\text { \% of } \\
\text { Cumulative } \\
\text { Variance }\end{array}$ \\
\hline $\mathbf{1 2}$ & Critical factors & $\mathrm{F}_{19}$ & $\begin{array}{l}\text { Ready to shift job at } \\
\text { same position in a } \\
\text { different } \\
\text { organization. } \\
\text { Employer overdrive } \\
\text { the employees }\end{array}$ & 0.586 & 1.01 & 4.20 & 42.35 \\
\hline
\end{tabular}

KMO 0.715

\subsection{FACTOR 1: JOB SATISFACTION AND SELF ESTEEM}

This suggests that factor 1 is the combinations of four variables. Faculty of Public Sector University perceives that there exists job satisfaction and self esteem. This factor explains (7.965\%) variance with 4 statements. Highest coefficient is for the statement $\mathrm{F}_{3}$, "Good relationship with co-workers" (0.639), followed by $F_{12}$ "Faculty members have friendly relations with each other" $(0.669)$ whereas next variable $F_{13}$ states that "Fellow colleagues are ready to help in distress" $(0.708)$ and one more statement which is extracted in factor 1 is $F_{16}$ "feeling of satisfaction after performing my work". Our results go hand in hand with the results of study conducted by Schulz and Pauline (2009), Johansson and Heikinaro(2004) who too found that teachers derived most of their job satisfaction from interpersonal relations.

\subsection{FACTOR 2: EFFORT RECOGNITION AND CAREER PROGRESSION}

This factor explains a combination of 5 statements with $7.309 \%$ of variance. The statement $\mathrm{F}_{7}$ scored the highest score. It is sufficient motivational strategies" (0.577), followed by $\mathrm{F}_{8}$ "support from top management is helpful in accomplishing a task" $(0.628)$. The statement $F_{9}$ states that "university recognizes and acknowledge my work" with factor loadings 0.643 is also a combination of $F_{10}$ "Adequate opportunities for self improvement and career progression" (0.515) and statement $F_{24}$ All the faculty members generally support all the members of the universities with factor loadings 0.695. Effort recognition and career progression also fall in line with the findings of Jenkinsons and Chapman (1990), Sweeney (1981).

\subsection{FACTOR 3: EMPLOYEE LOYALTY AND GROWTH}

This factor explains $6.032 \%$ of variance with 4 statements. These statements indicate that employees committed towards their duties and sufficient promotional opportunities are provided to deserving employees. The results contradict with studies conducted by Sonmezer and Eryaman (2008).

\subsection{FACTOR 4: QUALITY ON WORK PLACE}

Public university provides maximum facilities to conduct research work as well as to perform other activities. Factor $4^{\text {th }}$ explaining $4.920 \%$ of variance with 2 statements. The statement $F_{2}$, "University provides maximum facilities for doing to my work properly" $(0.688)$ followed by $F_{17}$ "Feeling good about the quality of work performed" (0.515). Bhanugopal et al. (2008) also found that there is correlation between quality of work life and work environment.

\subsection{FACTOR 5: CONDUCIVE ENVIRONMENT}

The $5^{\text {th }}$ factor explains $4.897 \%$ of variance of 2 statements. The highest coefficient is 0.725 in case of the statement $\mathrm{F}_{6}$, "Good safety measures adopted at my university" followed by $\mathrm{F}_{22}$, "I do not feel under pressure from anybody in carrying out my duties" (0.579) employees feels comfortable is this environment and 
work efficiently. It is also found in the study of Mirvis and Lawler (1984) that quality of work life is associated to working environment, working hours and safe working conditions.

\subsection{FACTOR 6: LOWER SELF ESTEEM}

Factor 6 enlists negative statements which lead to low the morale of employees. It consists of 2 statements. Factor 6 explains $4.820 \%$ of variance. The highest coefficient is 0.816 in case of statement $F_{18}$, "There are many political problems in this university" and $\mathrm{F}_{27}$, "Most of my activities are routine and boring" with factor loadings of 0.484 .

\subsection{FACTOR 7: EMPLOYEE DEVELOPMENT}

Factor 7 enlists statements related to employee development. $7^{\text {th }}$ factor explains $4.679 \%$ of variance with 2 statements. The statement $F_{21}$, "I am developing new skills and abilities at work" 0.704 followed by $F_{34}$, "My superior always allows to attend refresher courses and conferences" with factor loading of 0.558 .

\subsection{FACTOR 8: WORKLOAD OTHER THAN TEACHING}

This factor is a combination of 2 statements with $4.487 \%$ of variance. These statements create extra burden other than teaching on university faculty.

\subsection{FACTOR 9: RATIONALITY}

Factor 9 enlists favorable statements which lead to job satisfaction among public sector university faculty. It consists of 2 statements. Factor 9 explains $4.64 \%$ of variance. The highest coefficient is 0.754 , in case of statement $\mathrm{F}_{11}$, "Favoritism does not play any part in the Institution" and $\mathrm{F}_{25}$, "Faculty members are given recognition for their creative work" $(0.511)$.

\subsection{FACTOR 10: ORGANIZATIONAL SATISFACTION}

The $10^{\text {th }}$ factor explains $4.309 \%$ of variance with 2 statements the statement $\mathrm{F}_{2}$ scores highest score, "Job security exists at my university" (0.741), followed by $\mathrm{F}_{14}$ "I feel that my superiors give reasonable attention to my suggestions as regards method of work" $(0.566)$.

\subsection{FACTOR 11: ORGANIZATION COMMUNICATION AND ECONOMIC BENEFITS}

This factor explains $4.269 \%$ of the variance with 2 statements. This factor features that there is two way communications to make healthy environment and economic benefits are reasonably provided to the faculty. The highest varimax coefficient is secured by the statement $\mathrm{F}_{1}$, "There is reasonable periodical increase in my salary" $(0.795)$, followed by $F_{23}$, "There is an active flow of ideas" with factor loadings 0.501 .

\subsection{FACTOR 12: CRITICAL FACTORS}

The factor $12^{\text {th }}$ explains $4.205 \%$ of variance with 2 negative statements. The statement $F_{19}$, "Ready to shift job at same position in a different organization" (0.586) followed by $F_{26}$, "Employer overdrive the employees" with factor loadings of $0.70 \%$.

\subsection{PERCEPTION OF PRIVATE UNIVERSITY TEACHERS -A FACTOR ANALYSiS APPROACH}

Out of 34 factors only 12 factors extracted together with variance for $71.133 \%$ of total variance, so it is possible to economize on the number of variables from 34 to 12 . The $1^{\text {st }}$ factor explains the largest position of the total variance. The second factor for the most of the residual variance, subject to being uncorrelated with the first factor. The Eigen values for the factors are in decreasing order of magnitude as we move from variable 1 to 12 . Factor 1 accounts for variance 5.934 which $(5.934 / 34)$ or $17.454 \%$ of total variance. Likewise $2^{\text {nd }}$ factor accounts for $(3.056 / 34)$ or $8.989 \%$ of total variance and so on. Table 5 indicates that 12 factor have been extracted. 
TABLE II. Principal Component Analysis with Varimax Rotation- Private Sector University

\begin{tabular}{|c|c|c|c|c|c|c|c|}
\hline $\begin{array}{c}\text { Factor } \\
\text { Number }\end{array}$ & $\begin{array}{c}\text { Name of } \\
\text { Dimensions }\end{array}$ & Label & Statement & $\begin{array}{l}\text { Factor } \\
\text { loading }\end{array}$ & $\begin{array}{c}\text { Eigen } \\
\text { Values }\end{array}$ & $\begin{array}{c}\% \text { of } \\
\text { variance }\end{array}$ & $\begin{array}{c}\% \text { of } \\
\text { Cumulative } \\
\text { variance }\end{array}$ \\
\hline 1 & $\begin{array}{l}\text { Job Satisfaction } \\
\text { and Self Esteem }\end{array}$ & $\begin{array}{l}\mathrm{F}_{3} \\
\mathrm{~F}_{12} \\
\mathrm{~F}_{13} \\
\mathrm{~F}_{15} \\
\mathrm{~F}_{14} \\
\mathrm{~F}_{16}\end{array}$ & $\begin{array}{l}\text { Good relationship with co- } \\
\text { workers } \\
\text { Friendly relations with each } \\
\text { other } \\
\text { Fellow colleagues ready to } \\
\text { help in distress } \\
\text { Feeling of success } \\
\text { Superiors give reasonable } \\
\text { attention to my suggestions } \\
\text { I feel satisfied after } \\
\text { reforming my work }\end{array}$ & $\begin{array}{l}0.561 \\
0.742 \\
0.686 \\
0.702 \\
0.583 \\
0.526\end{array}$ & 5.93 & 8.94 & 8.94 \\
\hline 2 & $\begin{array}{c}\text { Effort } \\
\text { Recognition } \\
\text { and } \\
\text { Organizational } \\
\text { Communication }\end{array}$ & $\begin{array}{l}F_{9} \\
F_{21} \\
F_{23} \\
F_{24} \\
F_{25}\end{array}$ & $\begin{array}{l}\text { University recognizes and } \\
\text { acknowledge my work } \\
\text { I am developing my skills } \\
\text { and abilities at work } \\
\text { There is an active flow of } \\
\text { ideas } \\
\text { Co-workers support each } \\
\text { other } \\
\text { Faculty members are given } \\
\text { recognition for their work }\end{array}$ & $\begin{array}{l}0.512 \\
0.572 \\
0.580 \\
0.626 \\
0.800\end{array}$ & 3.05 & 7.90 & 16.84 \\
\hline 3 & $\begin{array}{l}\text { Quality on Job } \\
\text { Freedom }\end{array}$ & $\begin{array}{l}\mathrm{F}_{6} \\
\mathrm{~F}_{7} \\
\mathrm{~F}_{8}\end{array}$ & $\begin{array}{l}\text { Good safety measures } \\
\text { adopted at university } \\
\text { Sufficient motivational } \\
\text { strategies } \\
\text { Support from top level } \\
\text { management }\end{array}$ & $\begin{array}{l}0.651 \\
0.588 \\
0.703\end{array}$ & 2.22 & 7.39 & 24.24 \\
\hline 4 & $\begin{array}{l}\text { Employee } \\
\text { loyalty and } \\
\text { Growth }\end{array}$ & $\mathrm{F}_{1}$ & $\begin{array}{l}\text { There is reasonable } \\
\text { periodical increase in my } \\
\text { salary }\end{array}$ & 0.559 & & & \\
\hline
\end{tabular}




\begin{tabular}{|c|c|c|c|c|c|c|c|}
\hline $\begin{array}{c}\text { Factor } \\
\text { Number }\end{array}$ & $\begin{array}{c}\text { Name of } \\
\text { Dimensions }\end{array}$ & Label & Statement & $\begin{array}{l}\text { Factor } \\
\text { loading }\end{array}$ & $\begin{array}{l}\text { Eigen } \\
\text { Values }\end{array}$ & $\begin{array}{c}\% \text { of } \\
\text { variance }\end{array}$ & $\begin{array}{c}\% \text { of } \\
\text { Cumulative } \\
\text { variance }\end{array}$ \\
\hline & & $\begin{array}{l}\mathrm{F}_{28} \\
\mathrm{~F}_{29}\end{array}$ & $\begin{array}{l}\text { Faculty members in this } \\
\text { university communicate } \\
\text { well with each other } \\
\text { All members generally } \\
\text { committed to their work }\end{array}$ & $\begin{array}{l}0.850 \\
0.769\end{array}$ & 2.17 & 6.37 & 30.61 \\
\hline 5 & $\begin{array}{l}\text { Work load } \\
\text { other than } \\
\text { Teaching }\end{array}$ & $\begin{array}{l}\mathrm{F}_{32} \\
\mathrm{~F}_{33} \\
\mathrm{~F}_{34}\end{array}$ & $\begin{array}{l}\text { I am too much burdened for } \\
\text { research work } \\
\text { My university organizes } \\
\text { FDP from up gradation of } \\
\text { faculty } \\
\text { Support to attend } \\
\text { conferences and refresher } \\
\text { courses }\end{array}$ & $\begin{array}{l}0.672 \\
0.730 \\
0.703\end{array}$ & 1.83 & 6.32 & 36.94 \\
\hline 6 & $\begin{array}{l}\text { Lower Self } \\
\text { Esteem }\end{array}$ & $\begin{array}{l}\mathrm{F}_{18} \\
\mathrm{~F}_{27}\end{array}$ & $\begin{array}{l}\text { There are many political } \\
\text { problems in this university } \\
\text { Most of my activities are } \\
\text { routine and booking }\end{array}$ & $\begin{array}{l}0.766 \\
0.677\end{array}$ & 1.68 & 5.83 & 42.78 \\
\hline 7 & Work Pressure & $\begin{array}{l}\mathrm{F}_{19} \\
\mathrm{~F}_{30}\end{array}$ & $\begin{array}{l}\text { I am ready to join if same } \\
\text { type of job under same } \\
\text { terms and conditions in a } \\
\text { different organization. } \\
\text { I have no time to pursue my } \\
\text { area of interest }\end{array}$ & $\begin{array}{l}0.837 \\
0.511\end{array}$ & 1.52 & 5.42 & 48.20 \\
\hline 8 & $\begin{array}{c}\text { Opportunity of } \\
\text { Growth }\end{array}$ & $\begin{array}{l}\mathrm{F}_{10} \\
\mathrm{~F}_{22}\end{array}$ & $\begin{array}{l}\text { Adequate opportunities for } \\
\text { self improvement and career } \\
\text { progression } \\
\text { I do not feel under pressure } \\
\text { from anybody in carrying } \\
\text { out my duties }\end{array}$ & $\begin{array}{l}0.585 \\
0.835\end{array}$ & 1.38 & 5.00 & 53.20 \\
\hline 9 & Critical Factors & $\begin{array}{l}\mathrm{F}_{26} \\
\mathrm{~F}_{31}\end{array}$ & $\begin{array}{l}\text { Employer overdrive the } \\
\text { employees } \\
\text { I have to do too much } \\
\text { clerical work }\end{array}$ & $\begin{array}{l}0.538 \\
0.583\end{array}$ & 1.28 & 4.78 & 57.98 \\
\hline 10 & Rationality & $\mathrm{F}_{4}$ & $\begin{array}{l}\text { There is rational } \\
\text { performance and appraisal } \\
\text { system. }\end{array}$ & 0.528 & & & \\
\hline
\end{tabular}




\begin{tabular}{|l|c|l|l|l|l|l|l|}
\hline $\begin{array}{c}\text { Factor } \\
\text { Number }\end{array}$ & $\begin{array}{c}\text { Name of } \\
\text { Dimensions }\end{array}$ & Label & Statement & $\begin{array}{c}\text { Factor } \\
\text { loading }\end{array}$ & $\begin{array}{c}\text { Eigen } \\
\text { Values }\end{array}$ & $\begin{array}{c}\text { \% of } \\
\text { variance }\end{array}$ & $\begin{array}{c}\text { \% of } \\
\text { Cumulative } \\
\text { variance }\end{array}$ \\
\hline $\mathbf{1 1}$ & $\begin{array}{c}\text { Quality of } \\
\text { Work } \\
\text { Independent } \\
\text { Factor) }\end{array}$ \\
\hline $\mathbf{1 2}$ & $\begin{array}{c}\text { Organizational } \\
\text { satisfactions }\end{array}$ & $\mathrm{F}_{17}$ & $\begin{array}{l}\text { Favoritism do not ply and } \\
\text { part in the institutions }\end{array}$ & 0.836 & 1.05 & 4.77 & 62.77 \\
If feel good about the quality & 0.785 & 1.02 & 4.20 & 66.97 \\
\hline
\end{tabular}

KMO=0.630

\subsection{FACTOR 1: Job SATISFACTION AND SELF ESTEEM}

The first factor explains $8.949 \%$ of the total variance with 6 statements. The results go hand in hand with the results of study conducted by Schulz and Pauline (2009), Johansson and Heikinaro (2004) who too found that teachers derived most of their job satisfaction from interpersonal relations.

\subsection{FACTOR 2: EFFECT RECOGNITION AND ORgANIZATIONAL COMMUNICATION}

This factor explains $7.905 \%$ of the variance with 5 statements. The highest coefficient $0.800 \%$ is scored by the statement $F_{25}$, "Faculty members are given recognition for their work" followed by $F_{24}$, "Co-workers support each other" (0.626). The findings of the study also matched with Islam (2012). He conducted study regarding the factors affecting quality of work life among employees of private limited companies in Bangladesh.

\subsection{FACTOR 3: QUALITY ON JOB FREEDOM}

The factor explains $7.392 \%$ of the total variance with 3 statements. The highest coefficient is scored by the statement $\mathrm{F}_{8}$, "Support from top management". (0.703), followed by $\mathrm{F}_{6}$, "Good safety measures" adopted at university (0.651). The statement which scored least is $\mathrm{F}_{7}$, "Sufficient motivational strategies" (0.588). As explained by Owens (2006), that commitment has a major and constructive influence on job performance and on retaining workforce.

\subsection{FACTOR 4: EMPLOYEe LOYALTY AND GROWTH}

The $4^{\text {th }}$ factor explains $6.371 \%$ of variances with 3 statements. The statement $F_{28}$, "Faculty members communicate well with each other" has scored highest coefficient (0.850), followed by 2 statements $\mathrm{F}_{29}$, "All members generally committed to their work" $(0.769)$ and $\mathrm{F}_{1}$, "There is reasonable increase in my salary" $(0.559)$.

\subsection{FACTOR 5: WORKLOAD OTHER THAN TEACHING}

This factor explains $6.371 \%$ of variance with 3 statements in which employees feel stressed with high commitment work system i.e. trainings, meetings and involvement in job.

\subsection{FACTOR 6: LOWER SELF ESTEEM}

The $6^{\text {th }}$ factor explains $5.839 \%$ of the total variance with 2 statements. The high coefficient is scored by the statement $\mathrm{F}_{18}$, "There are many political problems in this university" $(0.766)$ followed by $\mathrm{F}_{27}$, "Most of my activities are routine and boring" $(0.677)$. 


\subsection{FACTOR 7: WORK PRESSURE}

This factor explains $5.420 \%$ of the total variances with 2 statements. Due to work pressure in private universities; employees are ready to join the same position in some other organization.

\subsection{FACTOR 8: OPPORTUNITY OF GROWTH}

The $8^{\text {th }}$ factor explains $5.002 \%$ of variance with 2 statements. The findings of the study also fall in line with Sandrick (2003) found that intrinsic job satisfaction, job delight was a better predictor of self esteem and opportunities of growth and career achievement are helpful to retain employees in an organization.

\subsection{FACTOR 9: CRITICAL FACTORS}

This factor explains $4.787 \%$ of variance with 2 statements. The highest coefficient is scored by $\mathrm{F}_{26}$, "Employer over drive the employees" (0.583) followed by $\mathrm{F}_{31}$, "I have to do too much clerical work" $(0.583)$.

\subsection{FACTOR 10: RATIONALITY}

This factor explains $4.780 \%$ of the total variance with 2 statements. The rationality among performance appraisal of faculties also fall in line with the results of study Aldakhilallah and Parente (2002) who serves as revised version of outdated methods of performance evaluation in the effective evaluation of the performance of faculties that fits with the idea of Total Quality Management (Almalki, 2012; Almalki, Fitzgerald \& Clark; 2011).

\subsection{FACTOR 11: QUALITY OF WORK}

This factor explains $4.20 \%$ of the total variance with only one statement $F_{17}$, "I feel good about the quality of work performed" (0.785). This is an Independent factor. Itself it is an important factor which is essential to evaluate overall work environment.

\subsection{FACTOR 12: ORGANIZATIONAL SATISFACTION}

The $12^{\text {th }}$ factor explains $4.156 \%$ of the total variance with 2 statements the statement $F_{21}$ "Job security exists in my university" $(0.713)$ followed by $\mathrm{F}_{5}$, "Effective promotional opportunities exist in my university" (0.671).The results also went along with findings of Moses (1999), Gupta and Sharma (2010) that they offer facility of self development and provides prospects to improve their job. There is correlation between quality of work life, job security and opportunities of career growth.

\section{Comparison of Results of Factor Analysis for Public SeCtor and Private SECTOR UNIVERSITY}

Application of factor analysis to the responses of public sector and private sector teachers reveals 12 dimensions. Total variance explained by 12 factors was $62.35 \%$ in case of public sector university teachers and $71.13 \%$ in case of private sector university teachers. These results reveals that factors discovered as important in quality of work life are greater preferred by private sector university teachers than public sector. There has been similarly in case of 3 factors i.e. Job satisfaction and self esteem and effort recognition and career progression and lower self esteem as this has been expressed through $1^{\text {st }}$ and $2^{\text {nd }}$ and $6^{\text {th }}$ factor by public sector and private sector University teachers. However, the importance of other factors differed considerably. The "work load other than teaching" appears as the $\mathrm{F}_{8}$ explaining $4.48 \%$ variance in case of public sector University, while factor $5^{\text {th }}$ explains $6.32 \%$ variance in case of private university teachers. There is a further 'Rationality' features as the $9^{\text {th }}$ factor with $4.64 \%$ of variance in case of public sector while it features as $\mathrm{F}_{10}$ with $4.78 \%$ of variance in private sector teachers. The 'Employee loyalty and growth is observed as the $3^{\text {rd }}$ factor by public sector university teachers with $6.37 \%$ of variance while it is at $4^{\text {th }}$ level in case private sector with $6.032 \%$ of variance and critical factors features as $12^{\text {th }}$ factor with $4.205 \%$ variance while it features at $9^{\text {th }}$ level with $4.787 \%$ for private sector teachers. The factor 'organizational satisfaction' features at $10^{\text {th }}$ level with $4.309 \%$ of variance in public sector where as at $12^{\text {th }}$ level with $4.156 \%$ of variance. Hence, private university teachers more affected by work load, rationality, critical factors and organization satisfaction. A comparison of two samples illustrates that the factors emerging from both university 
teachers are similar in constitution but private university teachers feel more work load others than teaching and critical factors as well as they feel there are more growth opportunities in Private Sector University.

\section{REFERENCES}

[1] M.H. Abel and J. Sewell, "Stress and Burnout in Rural and Urban Secondary School Teachers", Journal of Education Research, 92(5), 1999, 287-293.

[2] M. Almalki, G. Fitzgerald and M. Clark, "The Healthcare System in Saudi Arabia: An Overview", Eastern Mediterranean Health Journal, 17(10), 2011, 784-793.

[3] Anitha and S Rao, Quality of Work Life in Commercial Banks, (Discovery Publication House: New Delhi, 1998).

[4] N.A.S. Al-Doski , K.F. Aziz, "Job Satisfaction among Nurses in Iraq-Erbil City”, International Journal of Academic Research, 2(5), 2010, 86-89.

[5] N. Al-Enezi, R.I. Chowdhury, M.A. Shah and M. Al-Otabi, "Job Satisfaction of Nurses with Multicultural Backgrounds: A Questionnaire Survey in Kuwait”, Applied Nurses Research, 22 (2), 2009, 94-100.

[6] M.J. Almalk, G. FitzGerald and M. Clark, "The Relationship between Quality of Work Life and Turnover Intention of Primary Health Care Nurses in Saudi Arabia BMC Health Services Research", 12, 2012, 1-13.

[7] A. Tabassum, "Interrelations between Quality of Work Life Dimensions and Faculty Members Job satisfaction in the Private Universities of Bangladesh”, European Journal of Business and Management, 4 (2), 2012, 78-79.

[8] K.M. Barlow and G.A .Zangoro, "Meta-Analysis of the Reliability and Validity of the Anticipated Turnover Scale across Studies of Registered Nurses in the United States", Journal of Nurse Management, 18(7), 2010, 862-873.

[9] D. V. Berg, Teachers' Meaning Regarding Educational Practice, Review of Educational Research, 2002.

[10] Bhanugopal, Ramudu Alan and Fish, "The Impact of Business Crime on Expatriate Quality of Work-Life in Papua New Guinea", Australian Human Resources Institute,46(1), 2008, 68-84.

[11] G.A. Blix and J.W. Lee, "Occupational Stress among University Teachers", Journal of Educational Research, 36(2), 1994, 157-159.

[12] L.G. Bragard, D. Dupuis, C. R. Reynaert and A.M. Etienne, "Quality of Work Life in Doctors Working with Cancer Patients Occupational Medicine (London)", 62(1), 2012, 34-40.

[13] Brown, F. (1972), "Need Satisfaction of Educational Administrators", American Educational Research Association, ERIC Document Reproduction Service ED, 561-584.

[14] Carr, Jennifer Z, Schmidt, Aaron M, Ford J K, Deshon and Richard P (2003), "Climate Perceptions Matter: A Meta-Analytic Path Analysis Relating Molar Climate, Cognitive and Affective States and Individual Level Work Outcomes", Journal of Applied Psychology.

[15] S. Chander, and P. Singh, "Quality of Work Life in a University: An Empirical Investigation", Management and Labour Studies, 18(2), 1983, 97-101.

[16] A Chandramohan, Human Resource Management, (APH Publishing Corporation: New Delhi, 2008).

[17] P. Clark and B. Brooks "Quality of Nursing Work Life: Conceptual Clarity for the Future", Nurses Science Quarterly, 23(4), 2010, 301305.

[18] W.G. Cunningham, "Teacher Burnout-Solutions for the 1980s", The Urban Review, 15, 1983, 37-51.

[19] R. D. Nitish, "Towards and Appreciation of Quality of Work life and Quality of Work", Economic and Political Weekly, 19(20), 1984, 4649.

[20] R.V. Dick and U. Wagner, "Stress and Strain in Teaching: A Structural Equation Approach" Journal of Organizational Behavior, 18(3), 2000, 146-165.

[21] R. Drago, R.Caplan and R.Lynn, "New Estimates of Working Time Elementary School Teachers", Monthly Labour Review, 2005, 24-32.

[22] A.E. Eaton, M.E. Gordon, and J.H. Keefe, "The Impact of Quality of Work Life Programs and Grievances System Effectiveness on Union Commitment", International and Labor Relations Review, 45(3), 1992, 591-603.

[23] Efraty, David and M. J. Sirgy, "The Effects of Quality of Working Life (QWL) on Employee Behavioral Responses", Social Indicators Research, 22(1), 1990).

[24] Ellis and Pompli, "Quality of Working Life for Nurses", Commonwealth Department of Health and Ageing: Canberra, 2002).

[25] V. Evans, J.Ramsey, D. Johnson and D. Renwick, "Analysis of the Intrinsic and Extrinsic Stress Factors of Physical Education Teachers", Educational Research, 36(6), 1986, 17-22.

[26] S.M. Farrah, "Teachers Performance Motivation Los Angeles", CA: American Educational Research Association (ERIC Document Reproduction Service No. ED 206-096), 1981).

[27] S. Fattah, "Longitudinal Effects of Pay Increase on Teachers' Job Satisfaction-A Motivational Perspective" Journal of International Social Research, 3(10), 2010, 12-20.

[28] I.A. Friedman, "High and Low Burnout Schools-School Culture Aspects of Teachers Burnout", Journal of Educational Research, 84(6), 1991, 325-333.

[29] Gallie and Duncan, "The Quality of Working Life: Is Scandinavia Different”, Oxford Journal, 19, 2003, 61-79.

[30] A. Gani, "Quality of Work Life (QWL) in a State Setting: Findings of an Empirical Study", The Indian Journal of Labour Economics, 36 (4), 1993, 817-823.

[31] V. Gilgeous, "Manufacturing Managers: Their Quality of Working Life”, Integrated Manufacturing System”, 9(3), 1998, $173-181$. 
[32] S. Gosh, "Quality of Work Life in Two Indian Organizations Decisions", 19(2), 1992, 89- 102.

[33] C.J Grayson, "Management Science and Business Practice", Harvard Business Review, 51(4), 1973.

[34] P.S. Goodman, Quality of Work Life Projects in 1980's Industrial Relations Research Association, 1980, 487-494.

[35] Gupta and Sharma "Factor Credentials Boosting Quality of Work Life of BSNL Employees in Jammu Region", Sri Krishna International Research \& Educational Consortium, 1(2), 2010.

[36] Hannif and Zeenobiyah, "Call Centers and the Quality of Work Life: Towards a Research Agenda", Journal of Industrial Relations, 50(2), 2008, 271-284.

[37] S.J. Havolovic, “Quality of Work Life and Human Resource Outcomes” Industrial Relations, 30(3), 1991, 469-479.

[38] F. Herzberg, B. Mausner, and B. Snyderman, The Motivation to Work (2 $\left.2^{\text {nd }}\right)$, (New York: John Wiley, 1959).

[39] E. Hipps, and E. Smith, "Job Stress, Stress Related to Performance Based Accredited, Locus of Control, Age and Gender as related to Job Stress and Satisfaction in Teachers and Principals", British Educational Research Journal, 16(6), 1991, 25-28.

[40] B M Islam, "Factors Affecting Quality of Work Life: An Analysis on Employees of Private Limited Companies in Bangladesh", Global Journal of Management and Business Research, 12(18) 2012.

[41] R. Jenkinsons and W. Chapman, "Job Satisfaction of Jamaican Elementary School Teachers" International Review of Education, 36(3), 1990, 299-313.

[42] N. Johansson, and P. Heikinaro, "Job Satisfaction among Physical Education Teachers in Finland”, Proc. Pre Olympic Conf., Athens, 2004.

[43] A. Kaur "Quality of work life, National foundation of Indian Engineers", 2012.

[44] C. Kaur, Education in Punjab (A Historical Study), (Intellectual Publishing House: New Delhi, 1992).

[45] A. A. Khan, Human Resource Management and Industrial Relations ( $\left.2^{\text {nd }}\right)$, (Abir Publications: Dhaka, 2008).

[46] R. Knoop, "Job Involvement of Teachers", Toledo, OH: Mid Western Educational Research Association, ERIC Document Reproduction Service No. ED. 1980, 208-508.

[47] H. Kumar, and A. Shanubhogue, “Quality of Work Life: An Empirical Approach”, Manpower Journal, 32 (3), 1996, 17-24.

[48] P. Lam, "Work life, Career Commitment and Job Satisfaction as Antecedents of Career Withdrawal Cognition among Teacher Interest", Journal of Research and Development in Education, 28, 1995, 230-236.

[49] R.S.M Lawe, "Quality of Work Life and Performance: An ad hoc investigation of two key elements in the service profit chain model", International Journal of Service Industry Management, 11(5), 2000, 422 - 437.

[50] G. E. Ledford and E. E. Lawler, "Quality of Work Life Programs, Coordination, and Productivity", Journal of Contemporary Business, 11, 1982, 93-106.

[51] Lowe, G., \& Schellenberg, G. \& Shannon H. (2003), "Correlates of Transformational and Transactional Leadership: A Meta- Analytic Review of the MLQ Literature", Leadership Quarterly, Vol.7 (3), 385-425.

[52] C. K. Lutz, “A study on Job Satisfaction and Public Service Motivation: IZA” Discussion Paper No. 7935, 2014.

[53] Malarvizhi, "A Study on Quality Of Work Life In Jeppiaar Cements Private Limited, Mela Mathur, Perambalur-District”, (2012).

[54] J. Memeon, "Teacher Stress, Job Performance and Efficacy of Women School Teachers" Journal of Managerial Psychology, 20 (2), 2008, 178-187.

[55] G.V. Miller and C.J. Travers, "Ethnicity and the Experience of work: Job stress and Satisfaction of Minority Ethnic Teachers in the U.K.", International Review of Psychiatry, 17(5), 2005, 317-327.

[56] P.H. Mirvis and E.E. Lawler, “Accounting for the Quality of Work Life”, Journal of Occupational Behavior, 5, 1984, 197-212.

[57] S. Mishra and B. Gupta, "Work Place Motivators and Employee's Satisfaction: A Study on Retail Sector in India", The Journal of Industrial Relations, 44(3), 2009, 509-517.

[58] M. Mount, R. Ilies and E. Johnson, "Relationship of Personality Traits and Counter Productive Work Behaviors: The Mediating Effects of Job Satisfaction", Personnel Psychology, 2006.

[59] G.S. Mourkani and S.K. Avand, "A Study of the Relationship between Quality of Work Life and Entrepreneurship of the Faculty and Staff Members: A Case Study", Journal of Basic and Applied Scientific Research ISSN No. 2090-4304, 3(9), 2013, 119-125.

[60] Nadeem, B. Mudasir, "Research on Leadership Behaviour of Educational Administrators - A Critical Review of Literature" Scholarly Journal of Education, 1(2), 2012, 20-30.

[61] J.S. Okpara, "The Impact of Salary Differential on Managerial Job Satisfaction: A Study of the Gender Gap and its Implications for Management Education and Practice in a Developing Economy", Journal of Business Development Nations, 8, 2005, 66-92.

[62] T. Oshagbemi, "Gender differences in the Job Satisfaction of University Teachers", Journal of Work Management Review, 15(7), 2000, 331-340.

[63] Owens, "One More Reason not to Cut Your Training Budget: The Relationship between Training and Organizational Outcomes", Public Personnel Management, 2006.

[64] R L Payne, Organizations as Psychological Environments, In Warr, P. Psychology at Work (London: Penguin Book, 1987).

[65] D.B. Rao and D. Sridhar, Job Satisfaction of School Teachers, (Discovery Publishing House, New Delhi, 2003).

[66] R. C. Rose, L. S. Beh, , J. Uli and K. Idris, "Quality of Work Life: Implications of Career Dimensions", Journal of Social Sciences, 2 (2), 2006, 61-67.

[67] W.G.A. Rudd and S. Wiseman, "Sources of Disaster among a Group of Teachers", British Journal of Eco-Psychology, 32(8), 1962, 275291. 
[68] S. Subramaniam and Saravanan, "Empirical Study on Factors Influencing on Quality of Work Life of Commercial Bank Employees", European Journal of Social Sciences, 28(1), 2012, 119-127.

[69] N. G. Saraji and Dargahi, "Study of Quality of Work Life (QWL), Department of Health Care Management," School of Allied Medicine, Tehran University of Medical Sciences, Iran, 2006, 1053-1056.

[70] Sarmah, Bidula, Baruah and Manoshikha, "Job Stress among Secondary School Teachers", Indian Stream Research Journal, 2(8), 2012, 3436.

[71] L.K. Savery and M. Detiuk, "Principals' stress in Elementary and Secondary Schools", Education Quarterly Review, 16, 1985, 16-23.

[72] S. Schulze, and M.T. Pauline, "The factors that Promote the level of Job Satisfaction among school educators: An education Management Perspective", Education Development, 15(2), 2009, 141-153.

[73] S.A. Shalla and A. I. Fazili, "Quality of Work Life and Employee Job Satisfaction: A Dimensional Analysis", ABHINAV, International Monthly Refereed Journal of Research in Management \& Technology, 2014.

[74] Sheel, Shalini, Dr. Panday, D.K. (2012), "Quality of Work Life, Employee Performance and Career Growth Opportunities: A Literature Review”, International Journal of Multidisciplinary Research.

[75] Sirgy and M. Joseph Handbook of Quality-of-Life Research: An Ethical Marketing Perspective, (Dordrecht, Netherlands: Kluwer Academic Publishers, 2001).

[76] M.G. Sonmezer and M.Y. Eryaman, "Comparative Analysis of Job Satisfaction levels of Public and Private School Teachers", Journal of Theory and Practice in education, 4(2), 2008, 189-212.

[77] S.Hub and M. Kleiner, "Commitment on Work Related Expectations in FlexibleEemployment Forms: An Empirical Study of German IT Freelances", European Journal of Management, 28(1), 2010, 40-54.

[78] R.J. Straw and C.C. Heckscher, "QWL: New Working Relationships in the Communication Industry”,Labor Studies Journal, 9, 1984, 261274.

[79] P. SubaRao and Anitha, Strees Management in V.S.P Rao and Srilatha, Organisation strees, (Discovery Publishing House, New Delhi, 1991, 263-264).

[80] P. Sweeney, "Human Needs and Job satisfaction", Professional Journal, 32(1), 1981, 42-55.

[81] Trehan, Work Environment and Quality Life, (Regal Publications: India, 2008, 20-28).

[82] Thurman, "Job satisfaction: An International Overview", International Labour Review, 117(3), 1977, 249-250.

[83] B.A. Turner, \&. P. Chelleadurai, "Organization and Occupational Commitment, Intention to Leave and Perceived Performance of Intercollegiate Coaches", Journal of sport management, 2005, 682-686.

[84] A. J. Van Hooft and M. Q .De Jong, "Predicting Job Seeking for Temporary Employment using the Theory of Planned Behaviour: The Moderating Role of Individualism and Collectivism”, Journal of Occupational \& Organizational Psychology, 82(2), 2009, 295-316.

[85] Walton, "International Labour Organization: Recommended from the National Seminar on improving Quality of Work Life", Productivity, $22(4), 1982,79-83$.

[86] P B Warr, Job Characteristics and Mental Health InWarr, (P.Psychology at Work, London: Penguin Book, 1987).

[87] Weiss, Deconstructing Job Satisfaction: Separating Evaluations, Beliefs and affective Experiences. Human Resource Management Review, 2002, 173-194.

[88] J.S. Yoon, "Teacher characteristics as Predictors of Teacher-Student Relationship: Stress, Negative Effect of Self-Efficacy", International Journal of Social Behaviour and Personality, 30(5), 2002, 485-493.

[89] N.M. Zakari, N.I. Al Khamis and H.Y. Hamadi, "Conflict and Professionalism: Perceptions among Nurses in Saudi Arabia", International Nurses Review, 57(3), 2010, 297-304.

[90] M. Zembylas and E. Papanastarian, "Teacher Job Satisfaction in Cyprus: The Results of a Mixed-Methods Approach", Educational Research and Evaluation, 13(2), 2004, 305-331.

[91] K.P. Zingheim and R.J. Schuster, "Retaining Top Talent", Article published in Executive Excellence, 1, 2001, 8. 